AL IBTIDA: JURNAL PENDIDIKAN GURU MI (2019) Vol 6 (2): 231-243

DOI: http://dx.doi.org/ 10.24235/al.ibtida.snj.v6i2.3027

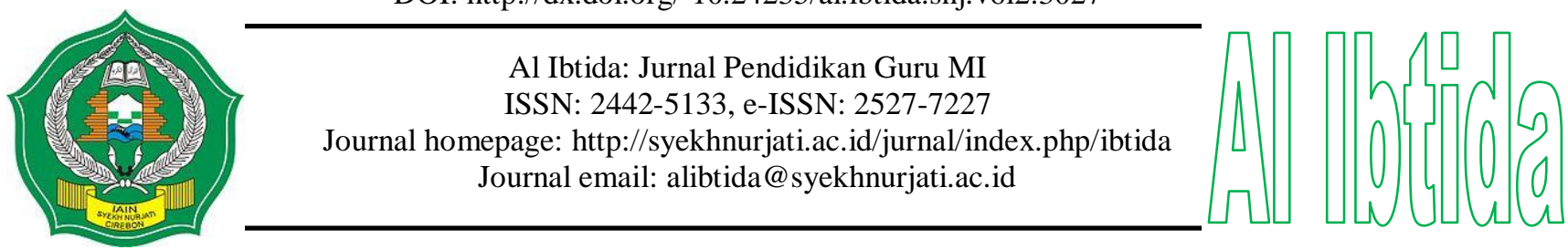

\title{
Analysis of Class Teacher Difficulties in Thematic Learning at Madrasah Ibtidaiyah
}

\author{
Ricka Tesi Muskania* \\ *Department of Madrasah Ibtidaiyah Teacher Education, Faculty of Tarbiyah and Teacher Training, \\ Institut Agama Islam Negeri Pontianak \\ Email: ricka.muskania@gmail.com
}

Received: August 09 ${ }^{\text {th }}$ 2018. Accepted: October 12 ${ }^{\text {th }}$ 2019. Published: October 29 $9^{\text {th }}, 2019$.

\begin{abstract}
This study was intended to describe the difficulties of first grade MI Al-Ikhwah Pontianak teachers in planning, implementing, and conducting assessments in thematic learning. This research adopts descriptive qualitative methods. Data collection techniques used were observation, interviews, and documentation. The data sources of this study were first grade teachers and Head of Madrasah Ibtidaiyah Al-Ikhwah. Data analysis techniques include data reduction, data presentation, and conclusions. The results showed that in the planning stage, teachers found difficulty in composing lesson plan which based on the conditions of the students. Besides, they also found difficulty in sorting out the basic competencies in the syllabus and lesson plans. At last, teachers found difficulty in preparing appropriate learning media for thematic learning. Meanwhile, at the implementation stage, the teacher found difficulties in adjusting the time allocation of learning instruction, difficult to facing the demands of completing one learning in one meeting, adjusting basic competencies with learning material in half a day, synergizing the delivery of objectives and activities as a whole with the allocation of time, and applying a scientific approach in learning. Whereas, at the teacher evaluation stage, it is difficult to use assessment instruments based on the condition of the students. Besides, the teachers found it difficult to adjust anecdotal notes with the assessment of the 2013 curriculum report cards. Therefore, the research findings should be used as an evaluation material for classroom teachers in applying thematic learning in classroom activities.
\end{abstract}

Keywords: teacher difficulties, thematic learning, 2013 curriculum.

\begin{abstract}
Abstrak
Penelitian ini bertujuan untuk mendeskripsikan kesulitan guru kelas satu MI AlIkhwah Pontianak dalam merencanakan, melaksanakan, dan melakukan penilaian dalam pembelajaran tematik. Penelitian ini menggunakan pendekatan kualitatif dengan metode deskriptif. Teknik pengumpulan data yang digunakan adalah observasi, wawancara, dan dokumentasi. Sumber data penelitian ini adalah guru kelas satu dan Kepala Madrasah Ibtidaiyah Al- Ikhwah. Teknik analisis data yang digunakan meliputi reduksi data, penyajian data, dan kesimpulan. Hasil penelitian menunjukkan bahwa pada tahap perencanaan guru mengalami kesulitan dalam menyusun RPP sesuai kondisi dan lingkungan peserta didik, guru sulit memilah kembali kompetensi dasar pada silabus dan RPP, dan guru sulit menyiapkan media
\end{abstract}


pembelajaran yang tepat dalam pembelajaran tematik. Sementara itu, pada tahap pelaksanaan guru mengalami kesulitan dalam menyesuaikan alokasi waktu dengan pembelajaran, sulit menghadapi tuntutan penyelesaian satu pembelajaran dalam satu kali pertemuan, sulit menyesuaikan KD dengan materi pembelajaran dalam setengah hari, sulit mensinergikan penyampaian tujuan dan kegiatan secara keseluruhan dengan alokasi waktu, dan sulit mengaplikasikan pendekatan saintifik dalam pembelajaran. Sedangkan pada tahap penilaian guru sulit menggunakan instrumen penilaian keterampilan dengan keadaan peserta didik dan guru sulit menyesuaikan catatan anecdot dengan penilaian pada raport kurikulum 2013. Oleh karena itu, temuan-temuan penelitian tersebut hendaknya dapat dijadikan sebagai bahan evaluasi bagi guru kelas dalam menerapkan pembelajaran tematik di kelas.

Kata kunci: kesulitan guru, pembelajaran tematik, kurikulum 2013.

\section{INTRODUCTION}

Primary education is the basic foundation for the next level of education. Therefore, education at the primary education level should be carried out in an appropriate manner so that it becomes a strong foundation for further education levels. At the level of primary education, beside there are elementary schools (SD), there are also Madrasah Ibtidaiyah (MI) which have advantages in Islamic subjects, such as Fiqh, Al-Qur'an Hadith, Moral Aqeedah, History of Islamic Culture and Arabic. And in recent years, the education curriculum in Indonesia has undergone several curriculum changes (Ahmad, 2014). The curriculum change that occurred was a change from the educational unit level curriculum (KTSP) to the 2013 curriculum (K13).

The change of KTSP (2006) curriculum to 2013 curriculum is expected to bring a new learning atmosphere. In this regard, Abong (2008) said that the development of knowledge and competency needs in the field of work requires an adjustment in the education curriculum by the government, specifically the Ministry of Education and Culture. In addition, this curriculum is expected to be able to produce a critical and creative generation of Indonesia in accordance with the demands of the times (Budiana, Sudarmin, \& Rodia, 2017). Curriculum changes should be carried out systematically, measurably, and planned as well as aimed at achieving national education goals.

In the 2013 curriculum, teachers are required to adjust to learning a scientific approach or in other words the learning process is emphasized more student-centered. This is reinforced by Rahayu's opinion (2016) that learning with the implementation of a scientific approach is a process that has currently been suggested in the 2013 curriculum. Along with the adoption of the 2013 curriculum, the learning model also changes according to the system, which is a learning model based on a theme that is well known as thematic learning. Thematic learning is part of integrated learning consisting of 10 models (Fogarty, 1991). Furthermore, Ain (2017) states that 
thematic learning is a learning activity that combines comprehensively and knowledge naturally links facts and ideas to understand the world.

Integrated learning models that can be applied at SD / MI level are webbed and integrated models. Integrated learning has provided understanding and some material has produced a new face called a theme (Murfiah, 2017). Thematic learning is expected to bring a new style of learning and improve students' understanding of the material by contextual learning (related to the surrounding environment). The inhibiting factor in thematic learning is the attitude of students who are less concerned about the lesson (Hasrawati, 2016). The main characteristics of the 2013 curriculum thematic learning are to focus on active learning in children and to create principles of learning that are fun and provide hands-on experience. However, the facts that occur, there are still many teachers who do not understand in creating a creative and enjoyable learning atmosphere, even though they have implemented thematic learning curriculum 2013 does not rule out the possibility of teachers proficient in planning, implementing and evaluating effectively.

Previous research that is relevant to this research has been conducted by Sukiniarti (2014) stating that thematic learning is only applied to low class. Though thematic learning must be applied from grade 1 to grade $6 \mathrm{SD} / \mathrm{MI}$. In addition, teachers also experience obstacles in planning, implementing, and conducting assessments and the effectiveness of strategies in thematic learning (Muhith, 2018). This study examines the difficulties experienced by teachers in schools that use thematic learning in 2 low classes and 2 high classes. Low class applying thematic learning is class 1 and 2, while high class is class 4 and 5. In addition, differences from this study are also found in the study location and class.

Furthermore, research has been conducted by Al Nashr (2018) about the inhibiting factors of teachers in thematic learning. The results of his research revealed that the low professional competence of teachers resulted in teachers experiencing difficulties in applying thematic learning. In addition, the low ability of students in terms of reading, writing and counting is also an obstacle for teachers in applying thematic learning in madrasah ibtidaiyah.

Integrative thematic learning is an approach that integrates various competencies from various subjects (Hidayah, 2015). Thematic learning units encourage the participation of all students through relevant themes (Ashokan \& Venugopal, 2016). Student involvement in thematic learning can be obtained through active, creative, interesting and meaningful learning (Min, Rashid, \& Nazri, 2012). Orientation of the involvement of students through active, creative, interesting, and meaningful learning can be obtained through the application of thematic learning in the 2013 Curriculum. So that the learning process can provide experience 
and provision for students to be able to compete with changes and developments so quickly (Sijabat, 2017).

In the 2014 school year, all schools in primary and secondary education must implement the 2013 Curriculum starting from grades 1-6. Madrasah Ibtidaiyah Al-Ikhwah is one of the elementary schools that has implemented the 2013 curriculum from 2014, but thematic learning in MI Al Ikhwah is applied in grades 1, 2, 4, and 5. Thematic learning should be applied without studying the subjects studied However, in reality the teacher implementing the thematic learning is still a separate system per subject, subjects that should have been integrated in the theme are taught in full in accordance with the demands of the 2013 integrated curriculum. This causes a case study research needed to examine the difficulties experienced by classroom teachers in carrying out thematic learning at MI Al Ikhwah. This study aims to describe the difficulties of first grade MI Al Ikhwah teachers in implementing thematic learning.

\section{METHODS}

This study uses a qualitative approach to the type of descriptive research. According to Ibrahim (2015), descriptive research is a way of working that characterizes and summarizes the various conditions, situations, or various observed variables. In the context of research, descriptive method is a way of working research intended to describe, describe, or describe the state of an object (reality or phenomenon) as it is, according to the situation and conditions at the time the research was conducted (Sugiyono, 2012).

This research was carried out at Madrasah Ibtidaiyah Al-Ikhwah, Pangeran Natakusuma Street, Pontianak in February 2018 with first-class MI Al-Ikhwah research subjects. Data collection techniques used were observation, interviews, and documentation. The data source of this research is first grade teacher and Head of Madrasah Ibtidaiyah Al-Ikhwah. Data analysis techniques used in the form of 1) data reduction, namely research data at MI Al-Ikhwah summarized into one of the data observations, interviews and documentation; 2) data display (data display), the data is presented in the form of a description containing information about the thematic learning activities of MI Al-Ikhwah's first grade, as well as exposure to the difficulties faced by teachers at the stages of planning, implementing, and evaluating students; 3) conclusion (verification). The data validity test technique used is the data triangulation technique of observations and implementation that is compared with the results of interviews and thematic learning documents. 


\section{RESULTS AND DISCUSSION}

\section{Thematic Learning Lesson Plan at First Grade of MI Al-Ikhwah}

Lesson planning is compiling the steps that will be implemented to achieve the goals that have been determined. Learning planning includes the preparation of learning plans and preparation of learning media and resources, learning assessment tools, and learning scenarios (Abong, 2008). Some of the difficulties of elementary school teachers in planning thematic learning are mapping the KI (Core Competences) / KD (Basic Competences) and indicators into specific themes, making thematic concept maps, compiling syllabi and lesson plans, and preparing teaching materials (Gularso, 2017).

Syllabus components based on Permendikbud No. 22 Concerning Basic and Secondary Education Process Standards are as in the following table 1.

Table 1. The Comparison of Syllabus Components between First Grade's Teacher and Permendikbud No 22 in the year of 2016

\begin{tabular}{cccc}
\hline No & Components & Yes & No \\
\hline 1 & School and Class Identity & $\sqrt{ }$ & \\
2 & Core Competency & $\sqrt{ }$ & \\
3 & Basic Competency & $\sqrt{ }$ & \\
4 & Theme & $\sqrt{ }$ & \\
5 & Main Materials & $\sqrt{ }$ & \\
6 & Learning Activity & $\sqrt{ }$ & \\
7 & Assessment & $\sqrt{ }$ & \\
8 & Time Allottment & $\sqrt{ }$ & $\sqrt{ }$ \\
9 & Learning Sources & & \\
\hline
\end{tabular}

Based on the syllabus component that has been updated by the government as in table 1 above, there is a similarity between the syllabus established by the government and the syllabus prepared by the teacher. It's just that, the syllabus prepared by the teacher has not included learning resources. In the learning material there are also differences in terms, where the syllabus that is compiled by the teacher uses the term learning activities and the subject matter, whereas the syllabus prepared by the government uses the term learning. Basically the two terms mean the same thing. This allows the teacher to find learning resources from various sources related to learning. However, it is better to include learning resources in the syllabus used so that it can facilitate the teacher in designing lesson plans.

In general, components in the lesson plan (RPP) consist of determining themes and titles, identity of subjects, competencies and indicators, determining material that is appropriate to the indicators, strategies and media as well as assessment and follow-up. While specifically the RPP component consists of learning objectives, basic competencies, indicators, learning materials, 
approaches, models and methods, media, tools/ materials and learning resources, learning steps and assessment.

The results of the comparison of the components of the RPP compiled by teachers with components compiled by Permendikbud can be seen in table 2 below.

Table 2. The Comparison of Lesson Plan Components between First Grade's Teacher and Permendikbud No 22 in the year of 2016

\begin{tabular}{clcc}
\hline No & \multicolumn{1}{c}{ Components } & Yes & No \\
\hline 1 & Learning Objectives & $\sqrt{ }$ & \\
2 & Basic Competency & $\sqrt{ }$ & \\
3 & Indicator & $\sqrt{ }$ & \\
4 & Learning Materials & $\sqrt{ }$ & \\
5 & Approach, Model. and Method & $\sqrt{ }$ & \\
6 & Learning Media and Sources & $\sqrt{ }$ & \\
7 & Learning Steps & $\sqrt{ }$ \\
8 & Assessment & $\sqrt{ }$ & \\
\hline
\end{tabular}

Based on table 2 above, it can be seen that the components of the lesson plan prepared by teachers and those prepared by the government in general are the same, only the layout is different. In the Permendikbud RPP component No. 22 of 2016, learning objectives lie in the position before the basic competencies without elaborating on core competencies, whereas in the RPP format used by teachers, learning objectives lie after indicators. The teacher uses a lesson plan from the government that has not been updated in format, therefore between theory and data is not appropriate. Teachers should design lesson plans that comply with the latest regulations.

So, at the planning stage, first grade teachers use learning tools sourced from the government, however in terms of syllabus components and lesson plans that are used are not in accordance with the latest references from Permendikbud No. 22 of 2016. In this case teachers must design their own learning tools Thematic adapted to the conditions of the class and students. Teachers need to follow the development of learning that has been updated by the government so that it can facilitate teachers in planning interesting learning. Class teachers must also be able to design strategies and media that interest students in learning.

\section{The Implementation of Thematic Learning at First Grade of MI Al-Ikhwah}

Characteristics of thematic learning that must be considered by the teacher are studentcentered, the separation of subjects is not very clear, develop skills, use the principle of playing while learning, develop communication, and present learning according to the theme (Indriani, 2015). Thematic learning is learning that provides opportunities for students to be able to actively participate in the learning process (Fernandes, 2017). The implementation of thematic learning refers to Permendikbud No. 22 of 2016 (Mendikbud, 2016). The presentation of the thematic learning activities carried out by the class teacher is as follows: 


\section{a. Preliminary activities}

In preliminary activities, teachers must: 1) prepare students (physical and psychological) to take part in the learning process; 2) provide contextual motivation according to the benefits and application of teaching materials in daily life, by providing examples and comparisons of local, national and international, and adjusted to the characteristics and levels of students; 3) determine the theme with students; 4) asking questions by linking prior knowledge with the material to be studied; 5) inform the learning objectives or basic competencies to be achieved; and 6) convey the scope of the material and explain the description of activities according to the syllabus.

Based on data obtained by researchers in the field, it is known that at the initial implementation stage, the teacher has prepared students physically and psychologically before learning. Class teachers have also used the surrounding environment to serve as an example in clarifying learning material. However, the class teacher did not convey the overall learning objectives and did not determine the theme together with students. So it can be concluded that in general class teachers have implemented the steps of learning activities well, although not yet at maximum.

\section{b. Main activity}

The core activity is the main activity that uses models, methods, learning media, and learning resources that are tailored to the characteristics of students and subjects to be integrated. The core activities include the students' skills in observing, asking, trying, associating, presenting, and creating activities which include aspects of attitude, knowledge and skills (Masnun, 2016). Attitude aspects in the learning process are all learning activities oriented to the competency stage that encourages students to carry out these activities. Meanwhile, aspects of knowledge are obtained through the activities of knowing, understanding, applying, analyzing, evaluating, and creating all of which are gradations of the cognitive domain. While the aspects of skills are obtained through observing, asking, trying, associating, serving, and creating. The entire contents of the material (topics and sub topics) of subjects derived from skills must encourage students to carry out the process of observation to the creation. In order to realize these skills, teachers need to apply learning that produces work based on problem solving (project based learning).

Based on the discussion of the implementation of thematic learning in first grade, it can be concluded that the teacher has not implemented the $6 \mathrm{M}$ process to the maximum. The teacher only invites students to observe, ask questions, try, associate, and serve. Even so, the teacher has created an interesting learning atmosphere by inviting students to actively sing and move to the song lyrics. This is done to encourage students to learn. So, the steps in the core activities carried 
out by classroom teachers are not in accordance with Permendikbud No. 22 of 2016 concerning Basic and Secondary Education Process Standards, where teachers only apply 5 of the 6M Scientific approaches, namely observing, asking, trying, associating, and serve. Limited time allocation makes thematic learning less than optimal. The teacher only uses 30 minutes for every 1 lesson provided by the school to deliver the material, while the time set by the government is 35 minutes per lesson. Time allocation affects the process of the teacher and students in observing, asking, trying, associating, presenting, and creating. The teacher must calculate the time spent in each activity carried out so that the material can be delivered as a whole according to basic competencies and indicators that have been determined.

\section{c. Closing activity}

In the closing activity, teachers and students reflect to evaluate 1) the entire set of learning activities and the results obtained to further jointly find direct and indirect benefits of learning outcomes; 2) provide feedback on the learning process and results; 3 ) follow up in the form of assigning tasks; and 4) inform the plan of activities for the next learning.

Based on the discussion of thematic learning implementation, it is known that when closing learning activities, the teacher concludes learning with students. In addition the teacher only gives oral tests and written tests. The teacher also did not provide feedback before the evaluation. However, the teacher still gives assignments to students who have not completed the training given by the teacher to be completed at home. In the final step the teacher closes the learning with prayer and closing greetings.

After discussing the process of implementing thematic learning in class, starting from the initial activities, core activities, and closing activities, the teacher has implemented the learning steps well. In the initial activity the teacher conveys the learning objectives in accordance with the RPP used, but the class teacher has not delivered the learning objectives as a whole. The lack of allocation of learning time makes teachers use makeshift media and provide basic explanations. To complete one basic competency and indicator the teacher must be good at using time so that the material is well presented. This also relates to the lesson plans used, teachers cannot implement learning activities that are in accordance with the lesson plans of the government. Therefore, teachers must design their own lesson plans that are appropriate to the circumstances and environment of students. The teacher only applies 5 out of $6 \mathrm{M}$ in learning, that is observing, asking, trying, associating and serving, but in certain learning the teacher applies 6 complete positive approaches. 


\section{Assessment for Thematic Learning at First Grade of MI Al- Ikhwah}

Based on Permendikbud No 23 year 2016 about assessment the learning process uses an authentic assessment approach that assesses the readiness of students, the process, and learning outcomes as a whole (Mendikbud, 2016). Assessment techniques consist of assessment of social and spiritual attitudes, assessment of test and non-test knowledge, assessment of skills of performance, projects, and student portfolios.

a. Attitude/ affective assessment

Attitude assessment is more aimed at fostering behavior in the context of character building students. This attitude assessment includes the spiritual attitude, which is accepting, practicing, and appreciating the teachings of the religion it embraces, social attitudes which include honest, disciplined, responsible, caring, polite, and confident behavior in interacting with family, friends, teachers, neighbors, and country. While the form of assessment conducted by classroom teachers is based on the results of interviews, namely the assessment of students' social and spiritual attitudes. The social attitude assessment conducted by the teacher is to assess the concern of students towards their friends who need help, such as lending a pencil, eraser and sailor. Whereas in the spiritual assessment that sees the order of students when reading prayers before learning. In addition to the assessment items mentioned above, more are specified in the form of reference assessment in student report cards in accordance with the 2013 curriculum assessment standards.

Based on the explanation of the theory and data above, it is known that the first grade teacher has implemented an assessment of students' social and spiritual attitudes. Regarding the assessment instruments, the teacher uses the form of instruments contained in the teacher's book. For low class teachers are required to foster student attitudes in the learning process. Therefore this assessment becomes an important aspect for determining the student's final grade.

b. Knowledge/cognitive assessment

This knowledge assessment includes written tests, oral tests, and assignments. Based on the results of research at school, the first grade teacher has conducted an assessment in the form of a test at the end of learning by giving a written test contained in the students' Thematic PR books published by one of the publishers. The book is provided from schools that refer to Permendikbud No. 20 of 2016.

In addition to written tests, the teacher has also given oral tests in the form of a number of questions answered directly by students based on the material that has been studied. Whereas the non-test assessment is done to assess the students' skills when doing the test given by the teacher, such as collecting the fastest and most recent assignments because of the delay in writing. 
However, teachers do not make anecdotal notes for students because teachers only use the assessments contained in the 2013 curriculum report cards.

Based on the discussion of the theory and the findings of the data above, it can be concluded that the teacher has carried out an assessment in the form of tests and non-tests in accordance with Permendikbud No. 23 of 2016. In carrying out this assessment of course teachers are required to provide an explanation in advance so that students understand what will be he did.

c. Skills/ psychomotor assessment

Referring to the form of assessment from Permendikbud No. 23 of 2016, there are several types of skills assessment (Mendikbud, 2016), namely first, performance appraisal. This performance appraisal emphasizes the process or product. Performance appraisals that emphasize products are product ratings, such as poster products, poetry, and crafts. Performance appraisal that emphasizes the process known as practice appraisal, such as playing an instrument, singing, playing soccer, observing using a microscope, playing roles, dancing, and reading poetry. Airasian \& Russell (2008) divided performance appraisal into 5 domains, namely: communication skills, psychomotor skills, athletic activity, concept acquisition, and attitude skills.

Second, project appraisal. Project appraisal is an assessment of a task completed in a certain period/ time. Project tasks are a series of activities ranging from planning, data collection, data processing, and reporting. Third, portfolio assessment. Portfolios are collections of documents resulting from assessments, works and awards, students in certain fields that reflect developments (reflective-integrative) in a certain period of time. Portfolio assessment is an extension of performance appraisal which includes several examples of students' products or performance (Airasian \& Russell, 2008).

Assessment indicators related to skills assessment are authentic assessment, in this case the teacher uses this assessment to adjust to the material being taught. Based on the findings in school, first grade teachers use the three components of the assessment, namely performance appraisal, projects, and collecting the results in the form of portfolios. The work produced by students such as making family photo frames, making plant/ fruit mosaics, making Pancasila chains from origami paper and so forth. Which is then hung and posted in the classroom. Another example in performance appraisal is the process of students reading aloud the text contained in a student's thematic book.

Based on the theory and interview data described above, it is known that the teacher has applied skills assessment in accordance with the thematic learning assessment theory. Students' work is hung and pasted, this is done so that students feel their work is appreciated. In the 
discussion above it has been explained that the teacher has implemented an assessment in accordance with the demands of the 2013 curriculum in thematic learning. Students can influence the assessment process by the teacher, because grades can be given according to their conditions.

Thematic learning is a way of learning and teaching in which many areas of the curriculum are linked together and integrated with themes (Okoro \& Okoro, 2016). Learning planning according to Permendikbud No. 22 of 2016 that teachers are required to prepare syllabi and lesson plans. Specifically, the lesson plan must consist of a minimum of school identity, theme, class, semester, time allocation, core competencies, basic competencies and indicators, learning objectives, materials, methods, media, learning steps, and assessment. Many teachers do not have the ability to implement the curriculum in the learning it does (Mudiono, Gipayana, \& Madyono, 2016). The difficulty of teachers in planning, implementing, and conducting assessments becomes the most important part that must be overcome, so that the thematic learning process can be in accordance with the expected goals.

The findings of this study are in line with the results of research by Muhith (2018) which states that teachers experience obstacles in planning, implementing, assessing and effectiveness of strategies in thematic learning. In addition, the teacher's difficulty is also in determining the theme. The findings of this study are in line with the results of research by Retnawati, Munadi, Arlinwibowo, Wulandari, \& Sulistyaningsih (2016) that teachers find it difficult to find problems and themes in thematic learning. Thematic learning is an approach that integrates various competencies from several subjects (Hidayah, 2015). This shows that a teacher who will carry out thematic learning must have the competence to integrate various competencies across subjects into an interesting, fun, and meaningful learning for students at the level of basic education especially in Madrasah Ibtidaiyah.

\section{CONCLUSION}

From the description of the results and discussion it can be concluded that the difficulty of first grade teachers on thematic learning, namely in planning thematic learning in class one, teachers have difficulty in preparing RPP that is in line with Ministry of Education and Culture Regulation number 22 in 2016, in the implementation of thematic learning in class, class teachers also still experience difficulties in implementing lesson plans in the learning process, in assessing thematic learning class teachers also still have difficulty using skills assessment instruments, and difficulties in adjusting anecdotal notes with assessments on the 2013 curriculum report cards. Therefore, the research findings should be used as evaluation material for class teachers in applying thematic learning in class. 


\section{REFERENCES}

Abong, R. (2008). Akselerasi Implementasi Kurikulum Tingkat Satuan Pendidikan (KTSP) dalam Pembelajaran. Jurnal At- Turats, 3(1), 37.

Ahmad, S. (2014). Problematika Kurikulum 2013 dan Kepemimpinan Instruksional Kepala Sekolah. Jurnal Pencerahan, 8(2), 98-108.

Ain, N. (2017). Holistic Thematic Learning in The Elementary School: Is It Thematic and Holistic. International Conference on Teacher Training and Education 2017. 158, pp. 919-928. Paris: Atlantis Press

Airasian, P. W., \& Russell, M. K. (2008). Classroom Assessment. New York: McGraw-Hill.

Alnashr, M. S. (2018). Analisis Faktor Penghambat Guru Madrasah Ibtidaiyah dalam Pembelajaran Tematik (Studi Kasus di MI Al-Hikmah Kajen, Margoyoso, Pati). Al Ibtida: Jurnal Pendidikan Guru MI, 5(2), 191-204.

Ashokan, V., \& Venugopal, K. (2016). Impact of Thematic Approach on Communication Skill in Preschool. Online Submission, 2(10), 394-397.

Budiana, S., Sudarmin, \& Rodia, S. (2017). Evaluasi Implementasi Kurikulum 2013 di Sekolah Pelaksana Mandiri. Innovative Journal of Curriculum and Educational Technology, 6(1), 45-57.

Fernandes, J. (2017). Penerapan Pembelajaran Tematik Kelas Rendah SD N 1 Blunyahan, Sewon, Bantul, Yogyakarta. Jurnal Pendidikan Guru Sekolah Dasar, 9(6), 866-872.

Fogarty, R. (1991). How to Integrate The Curricula. United States of America: IRI/Skylight Publishing.

Gularso, D. (2017). Analisis Kesulitan Dalam Perencanaan Pembelajaran Tematik di Sekolah Dasar. Jurnal Pendidikan Sekolah Dasar, 3(2), 61-74.

Hasrawati. (2016). Perangkat Pembelajaran Tematik di SD. AULADUNA Jurnal Pendidikan Dasar Islam, 3(1), 37-49.

Hidayah, N. (2015). Pembelajaran Tematik Integratif di Sekolah Dasar. Terampil Jurnal Pendidikan dan Pembelajaran Dasar, 2(1), 1-15.

Ibrahim. (2015). Metodologi Penelitian Kualitatif: Panduan Beserta Contoh Proposal Kualitatif. Bandung: Alfabeta.

Indriani, F. (2015). Kompetensi Pedagogik Mahasiswa Dalam Mengelola Pembelajaran Tematik Integratif Kurikulum 2013 Pada Pengajaran Micro di PGSD UAD Yogyakarta. Profesi Pendidikan Dasar, 2(2) 87-94.

Masnun, M. (2016). Penerapan Pendekatan Saintifik dalam Pembelajaran Tematik Terpadu. Al Ibtida: Jurnal Pendidikan Guru MI, 3(1), 1-12.

Mendikbud. (2016). Peraturan Menteri Pendidikan dan Kebudayaan No. 22 Tentang Standar Proses pendidikan Dasar dan Menengah. Jakarta: Kementerian Pendidikan dan Kebudayaan.

Mendikbud. (2016). Peraturan Menteri Pendidikan dan Kebudayaan No. 23 Tentang Standar Penilaian Pendidikan Dasar dan Menengah. Jakarta: Kementerian Pendidikan dan Kebudayaan.

Min, K. C., Rashid, A. M., \& Nazri, M. I. (2012). Teachers' Understanding and Practice towards Thematic Approach in Teaching Integrated Living Skill (ILS) in Malaysia. International Journal of Humanities and Social Science, 2(23), 273-281. 
Mudiono, A., Gipayana, M., \& Madyono, S. (2016). Developing of Integrated Thematic Learning Model through Scientific Approaching with Discovery Learning Technique in Elementary School. International Academic Institute for Science and Technology, 3(10), 19-27.

Muhith, A. (2018). Problematika Pembelajaran Tematik Terpadu di MIN III Bondowoso. Indonesian Journal of Islamic Teaching, 1(1), 45-61.

Murfiah, U. (2017). Model Pembelajaran Terpadu di Sekolah Dasar. Jurnal Pesona Dasar, 1(5), 57-69.

Okoro, C.O, \& Okoro, C.U. (2016). Teachers' Understanding and Use of Thematic Approach in Teaching and Learning of Social Studies in Rivers State. International Journal of Education, Learning and Development, 4(3), 64-69.

Rahayu, Y. M. (2016). Pengaruh Perubahan Kurikuum 2013 Terhadap Perkembangan Peserta Didik. Jurnal Logika, 18(3), 22-42.

Retnawati, H., Munadi, S., Arlinwibowo, J., Wulandari, N. F., \& Sulistyaningsih, E. (2016). Teacher's Difficulties in Implementing Thematic Teaching and Learning in Elementary Schools. The New Educational Review, 48(1), 201-212.

Sijabat, O. P. (2017). Thematic Character Based Learning in Primary School. Arts and Design Studies, 3(2), 381-386.

Sugiyono. (2012). Metode Penelitian Kuantitatif, Kualitatif dan R\&D (14 ed.). Bandung: Alfabeta.

Sukiniarti. (2014). Kendala Penerapan Pembelajaran Tematik di Kelas Rendah Sekolah Dasar. Perspektif Ilmu Pendidikan, 28(2), 120-128. 